\title{
Ornamental plant diversity, richness and composition in urban parks: studies in Metro Cebu, Philippines
}

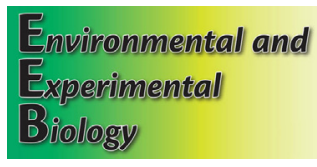

ISSN 2255-9582

UNIVERSITY OF LATVIA

\section{Precille Mae C. Flores ${ }^{1}$, Aime I. Fernandez ${ }^{1}$, Kathleen Jay U. Orozco', Rochelle Mae C. Endino', Jay P. Picardal'2, Jake Joshua C. Garces ${ }^{1,2 *}$}

${ }^{1}$ Biology Department, College of Arts and Sciences, Cebu Normal University, Cebu City 6000, Philippines

${ }^{2}$ Research Institute of Tropical Biology and Pharmacological Biotechnology, Cebu Normal University, Cebu City 6000, Philippines

${ }^{*}$ Corresponding author, E-mail: garcesjj@cnu.edu.ph

\begin{abstract}
Urban parks are essential for a city's sustainability. Thus, evaluating and determining the plants propagated in these urban parks is required for better future planning and for development of effective management strategies in urban green spaces in the Philippines. The study was conducted to determine native and exotic ornamental plant composition in the top five most visited urban public parks in Metro Cebu: Plaza Independencia, Senior Citizen Park, Fuente Osmeña Circle, Heritage Park and Plaza Hamabar. A total of 132 quadrats were established using the ground surveying technique to document all ornamental plants present. Diversity indices were also measured, which included abundance, richness, evenness, Shannon diversity and Simpson diversity indices. The chosen sampling sites were also categorized based on functional classification. In total, 28647 individuals of native and ornamental plants were recorded. In terms of richness, 100 plant species were identified in all parks (85 species in Plaza Independencia; 17 species in Senior Citizen's Park; 17 species in Fuente Osmeña Circle, 11 species in Heritage Park and 18 species in Plaza Hamabar). About 95\% of the species were exotic and only 5\% were native. Results on biological indices showed that Plaza Independencia was the most diverse in terms of the Shannon and Simpson diversity indexes, with the respective values of 2.775 and 0.896. In contrast, Senior Citizen Park had the lowest Shannon and Simpson diversity index (0.774 and 0.324, respectively). Plaza Hamabar had the highest evenness (0.743) while Senior Citizen's Park had the lowest evenness (0.273). Dominance of exotic ornamental plant species over native ones in the top five most visited parks can be explained by various factors such as park category, functional classification and management options.
\end{abstract}

Key words: exotic ornamental plants, Metro Cebu, native ornamental plants, Philippines, urban parks. Abbreviations: EOPs, exotic ornamental plants; NOPs, native ornamental plants.

\section{Introduction}

High biodiversity is a characteristic of a healthy ecosystem and is essential for the well-being of our planet (IUCN 2015; Lefcheck et al. 2015). However, its decline has been accelerating rapidly for the past five decades with slight signs of recovery (Bell et al. 2015). Introduction of exotic plants, which often results in their gradual proliferation and invasion, together with urbanization and extensive agriculture, are considered as the leading causes of biodiversity loss (Bellard et al. 2015). The drastic changes in the natural landscape caused by urbanization can negatively affect the composition and diversity of plant and animal communities, including pollinators, thus affecting ecological processes (Muller, Werner 2010; van Ham et al. 2013; Crompton 2016; Coldwell, Evans 2017; Grunewald et al. 2017). In particular, the actions of horticulturists and garden enthusiasts on acquiring exotic ornamental plants (EOPs) and native ornamental plants (NOPs) are human-mediated activities for plant invasion (DehnenSchmutz, Conroy 2018), resulting in increase of abundance and richness of EOPs in a given area. Moreover, even botanical gardens where EOPs and NOPs are collected for ornamental or conservation purposes are challenged due to the spread of EOPs (Hulme 2011). Significantly, most of the EOPs that were introduced and later propagated in urban parks and gardens have records of being invasive or becoming invasive thereafter (van Ham et al. 2013). Urban ecosystems provide green landscapes, such as parks, commonly used for leisure and physical activity, benefiting human health and well-being (Djoghlaf et al. 2010; Lundholm, Richardson 2010; FAO 2011; Bonebrake, Tom 2016). Cities therefore play an important role in conserving global biodiversity through the planning and management of urban green areas, including social, cultural interactions and economic factors (Müller, Werner 2010; UNEP 2012; 
De Wulf et al. 2018).

The Philippines is considered as one of the most biologically diverse countries in the world (FAO 2011; UNEP 2012). Apparently, incessant increase of human population and unrestrained utilization of natural resources in one of the cities of the Philippines - Metro Cebu - has been threatening wildlife habitats, leading to biodiversity loss (Hanski 2011). Another reason for biodiversity loss is the introduction of EOPs, which have become naturalized and have been able to proliferate and spread (Chase et al. 2011). These EOPs are widely used especially in parks for floriculture purposes. Thus, whether the inclusion or exclusion of urban parks as a vital component in promoting ecosystem biodiversity is an environmental issue or not, the subject must be thoroughly studied. The fragmentation and habitat loss of Cebu due to anthropogenic activities are still the main factors leading to the reduction of native biodiversity, including animals and other organisms (Szlávecz et al. 2011; Buczkowski, Richmond 2012; Dell et al. 2012; UN 2013; Garces, Genterolizo 2018). Plant communities dominated by EOPs in urban ecosystems result in numerous ecological problems (Gaertner et al. 2017; Li et al. 2018; van Kleunen et al. 2018). EOPs are known to be one of the greatest threats to ex situ conservation of NOPs, plant community structure and ecosystem functioning (Replan, Malaki 2017; Kruize et al. 2019). EOPs may establish negative relationships with NOPs (Corcos et al. 2020). Therefore, registration of the existing plant communities, and in particularly identifying the invasive potential of EOPs before their propagation and establishment in the landscape, is extremely important for native plant conservation (Bang et al. 2011; UNDP 2014; Hummel et al. 2017; Scovronick et al. 2017; DehnenSchmutz, Conroy 2018).

Plant inventory and biological indices are extremely important factors for species conservation at the community and ecosystem levels (Leger, Espeland 2010; Jeschke et al. 2014; Tobin 2018). They have been widely used to assess and describe the conservation status of communities and ecosystems, and to understand future responses to climate changes (Chase et al. 2011; Pyšek et al. 2012; Aydin et al. 2016; Foxcroft et al. 2017). Moreover, these factors inform about community dynamics; adaptation to dispersion and even the ability to compete for establishment (Pascual et al. 2010; Birch, Wachter 2011). Understanding the distribution of plants by use of biological indices in urban green areas is extremely important for the design and implementation of native plant management and conservation plans (Downey, Richardson 2016; Guiaşu, Tindale 2018). In this study, we aimed to determine the composition and diversity of native and exotic ornamental plant species in five minor and major urban parks in Metro Cebu, Philippines. Specifically, we analyzed (a) the proportion of NOPs and EOPs in urban parks and (b) the species richness, abundance, evenness and abundance of NOPs and EOPs in urban parks in Metro Cebu.

\section{Materials and methods}

\section{Description of the study area and context}

Cebu City is the capital of the island of Cebu, one of the provinces of the Philippines. The city is the center of industry and commerce of the entire province. It is situated $550 \mathrm{~km}$ south-east of Manila and listed as the second largest urban center of the country (OECD 2017). The total land area is 291.2 ha, comprising of 55.9 ha of urban area while the remaining area of 235.2 ha is classified as rural. Its estimated elevation is $900 \mathrm{~m}$ above sea level. The annual mean temperature is $26.5^{\circ} \mathrm{C}$ with highest and lowest monthly temperature of $34.8^{\circ} \mathrm{C}$ and $20.6{ }^{\circ} \mathrm{C}$, respectively (Cebu City Government-City Planning and Development Office 2017). The coldest month is January and the warmest month is May. The average annual rainfall is $1636 \mathrm{~mm}$ (old Lahug Airport) and $1670 \mathrm{~mm}$ (Cebu Customs House). Precipitation decreases from February to April, and gradually increases from May to July (PAGASA 2015; Garces et al. 2016). These environmental features are similar throughout Cebu City area and thus do not spatially affect the overall diversity, composition, and distribution of the plants in the study sites. This research focused mainly to the top five most visited urban public parks inside Cebu City (L. Macaraya, personal communication), which include two major parks, Plaza Independencia and Fuente Osmeña Circle and three minor parks, the Senior Citizens Park, Plaza Hamabar and Cebu Heritage Park (Fig. 1).

\section{Research design}

A ground surveying technique was employed, where the total number of EOPs and NOPs was determined by quadrat sampling method (Baxter 2014). A total of 132 quadrats with size $10 \times 10 \mathrm{~m}$ and 132 total quadrats were established in the parks. The surveyed plants were classified up to species level. Furthermore, species were classified according to plant life forms as trees, shrubs, and herbaceous plants (Akhtar, Bergmeier 2015). The chosen parks were categorized in two main aspects based on park age and functional classification. Parkes were classified as old and young parks. Parks developed before 1950 belong to old parks while those that were developed after 1950 were classified as young (Li et al. 2005). Functional classifications divided parks based on historic/cultural protection and family/ social recreation (Ummeh, Toshio 2017). The old, historic/ cultural protection parks were usually heritage sites while the old, social recreation parks were used for recreational activities and as cultural and community gathering places. Some of the new, historic/cultural protection parks are mostly minor parks established near infrastructures having significant traditions while other newly established parks are merely for family/social recreational activities. It is remarkable that less green space is available in these parks because of its underlying functional purposes. The total park area covered in this study was $43510 \mathrm{~m}^{2}$. The smallest park area was $1150 \mathrm{~m}^{2}$ and the largest was $24700 \mathrm{~m}^{2}$. 


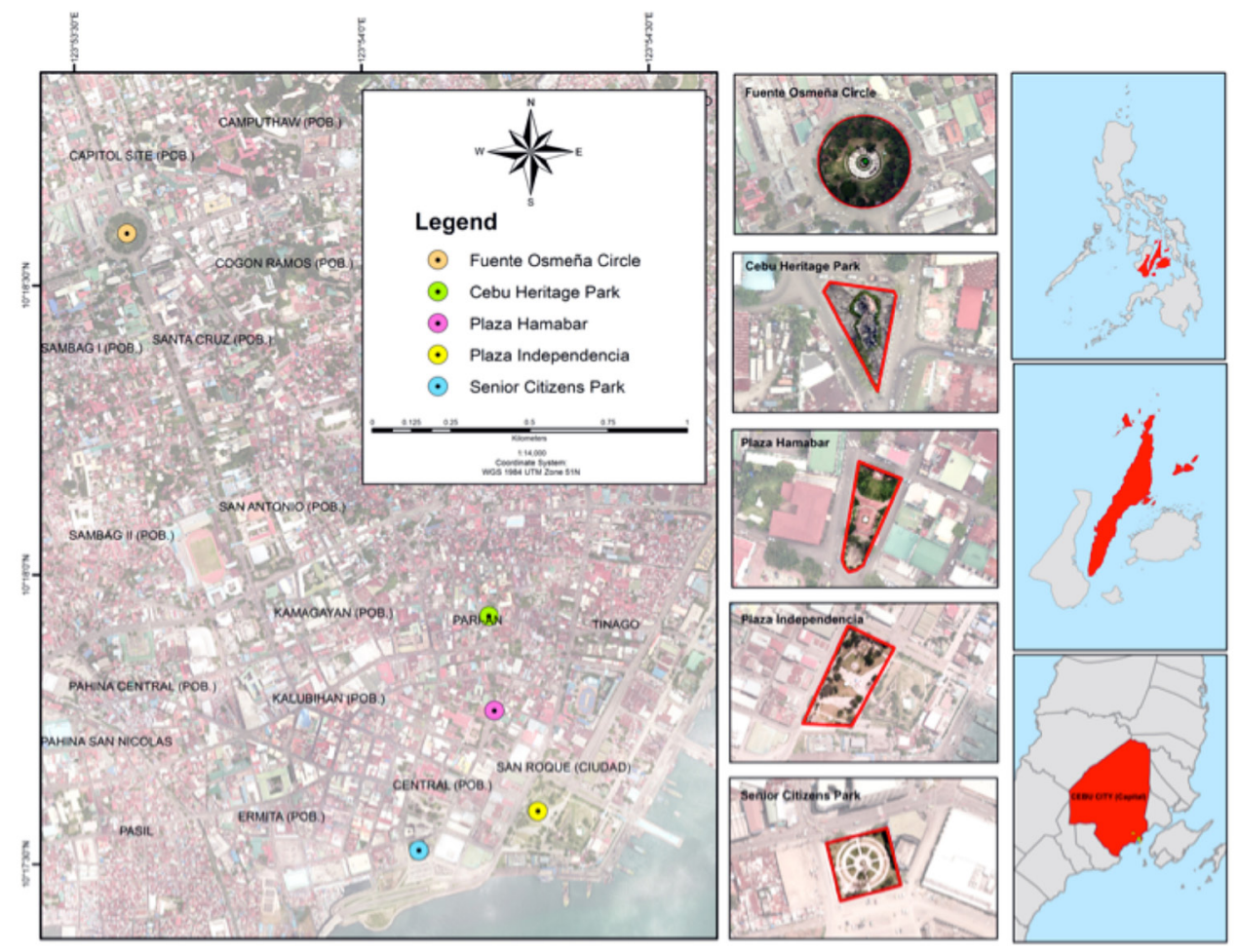

Fig. 1. Geographic location of the five studied urban parks in Metro Cebu, Cebu Island, Philippines.

\section{Data collection}

During personal visits, the researchers observed that there were only specific areas in the park intended for plant vegetation. Most of the plant communities were aggregated and therefore, selective sampling was used in placing the quadrats to ensure that shrub, herbaceous, and tree communities were included during the sampling procedure. Selective sampling is a technique used to provide accurate data especially if the chosen population is already identified (Han et al. 2020). Due to the restrictions of obtaining specimen vouchers, the images of each plant for identification were taken using a Canon EOS 1200D photographic camera, preferably from 8:00 to 17:00. In addition, the photographic method was based on the manual of Co's Digital Flora in the Philippines (Barcelona, Pelser 2015). Identified plants were taxonomically classified yo species level using mainly the monograph "A Pictorial Cyclopedia of Philippine Ornamental Plants $2^{\text {nd }}$ Edition" by Dr. Domingo Madulid as a reference and with the help of the Global Invasive Species Database, Pacific Island Ecosystem at Risk, Asia-Pacific Forest Invasive Species Network, and Botanic Gardens Conservation International. During the preliminary visit, researchers consulted with the park administration to obtain lists of all ornamental plants in the area and to obtain assistance during the proposed schedule of sampling.

\section{Data analysis}

The biological indices (i.e. species, abundance, richness, evenness and diversity) of NOPs and EOPs for each park were calculated using the summarized data from sample plots of shrub, herbaceous, and trees communities. The following formulae were used:

Species abundance $=($ total number of species $\mathrm{A} /$ total number of all species) $\times 100$;

Species richness $=$ number of species found in each quadrat.

Simpson diversity index $\mathrm{D}$ was calculated as

$$
D=1-\sum n_{i}\left(n_{i}-1\right) / N(N-1),
$$

where $n_{i}$ is the number of individuals, $N$ is the total number of species, $0=$ low diversity, $1=$ high diversity.

Pielou's evenness $(J)$ was calculated as

$$
J=H / \ln (S)
$$

where $H$ is the Shannon's index, $S$ is the number of species encountered (Smith, Smith 2000).

\section{Results}

A total of 28647 plant individuals were identified in the five most visited parks in Cebu City, Philippines (Table 1). Plaza Independencia had $71.36 \%$ (20 442 individuals), Senior Citizen's Park 14.09\% (4036 individuals), Fuente Osmeña Circle 4.61\% (1322 individuals), Heritage Park 8.51\% (2438 individuals) and Plaza Hamabar 1.43\% (409 individuals) of the total number. The surveyed plants were represented by 46 families and 85 genera of 100 different species (Fig. 2). Of the total species richness, 95\% were EOPs and 5\% were NOPs. In terms of species richness, the top three families with highest number of taxons were Asparagaceae with five genera and 12 species (Agave 
Table 1. List of species of exotic and native ornamental plants and their individual numbers in five urban parks in Metro Cebu, Philippines

\begin{tabular}{|c|c|c|c|c|c|c|c|c|}
\hline Family & Species & Status & $\begin{array}{c}\text { Heritage } \\
\text { Park }\end{array}$ & $\begin{array}{c}\text { Hamabar } \\
\text { Park }\end{array}$ & $\begin{array}{c}\text { Fuente } \\
\text { Osmeña } \\
\text { Circle }\end{array}$ & $\begin{array}{c}\text { Senior } \\
\text { Citizen's } \\
\text { Park }\end{array}$ & $\begin{array}{c}\text { Plaza } \\
\text { Indepen- } \\
\text { dencia }\end{array}$ & Total \\
\hline \multirow[t]{3}{*}{ Acanthaceae } & Crossandra infundibuliformis & EOP & - & 111 & - & 6 & 1681 & 1798 \\
\hline & Justicia sp. & EOP & - & & - & - & 9 & 9 \\
\hline & Ruellia tuberosa & EOP & - & 1 & - & - & - & 1 \\
\hline \multirow[t]{5}{*}{ Amaranthaceae } & Althernanthera polygonoides $\mathrm{cv}$. & EOP & - & - & - & - & 220 & 220 \\
\hline & Althernanthera sp. & EOP & - & - & - & - & 103 & 103 \\
\hline & Celosia cristata & EOP & - & - & - & - & 226 & 226 \\
\hline & Gomphrena globosa & EOP & - & - & - & - & 15 & 15 \\
\hline & Iresine herbstii & EOP & - & - & - & - & 281 & 281 \\
\hline \multirow[t]{2}{*}{ Amaryllidaceae } & Hippeastrum sp. & EOP & - & 4 & - & - & - & 4 \\
\hline & Zephyranthes rosea & EOP & - & - & - & - & 42 & 42 \\
\hline \multirow[t]{7}{*}{ Anacardiaceae } & Adenium obesum & EOP & 32 & - & - & - & 142 & 174 \\
\hline & Allamanda cathartica & EOP & - & - & - & - & 35 & 35 \\
\hline & Allamanda neriifolia & EOP & 20 & - & - & - & - & 20 \\
\hline & Catharanthus roseus & EOP & - & - & - & - & 8 & 8 \\
\hline & Mangifera sp. & EOP & - & - & - & - & 1 & 1 \\
\hline & Nerium oleander & EOP & - & - & - & - & 1 & 1 \\
\hline & Plumeria sp. & EOP & - & - & - & - & 23 & 23 \\
\hline Annonaceae & Polyalthia longifolia & EOP & - & 5 & 1 & - & - & 6 \\
\hline Apocynaceae & Tabernae montana pandacaqui & EOP & - & 53 & & 2 & 467 & 522 \\
\hline Araceae & Alocacia sp. & EOP & - & - & - & - & 1 & 1 \\
\hline Araliaceae & Polyscias scuttelaria & EOP & - & - & - & - & 1 & 1 \\
\hline Araucariaceae & Araucaria heterophylla & EOP & - & - & - & - & 2 & 2 \\
\hline Arecaceae/ & Cocos nucifera & EOP & - & - & - & - & 2 & 2 \\
\hline \multirow[t]{7}{*}{ Palmae } & Dypsis sp. & EOP & - & 1 & - & - & 31 & 32 \\
\hline & Licuala grandis & EOP & - & & - & - & 256 & 256 \\
\hline & Pinanga kuhlii & EOP & - & - & - & 5 & - & 5 \\
\hline & Ptychosperma macarthurii & EOP & & 8 & - & 25 & 1 & 34 \\
\hline & Rhapis excelsa cv. & EOP & 13 & - & - & - & - & 13 \\
\hline & Roystonea regia & EOP & - & 2 & - & - & - & 2 \\
\hline & Veitchia merrillii & NOP & - & - & - & - & 16 & 16 \\
\hline \multirow[t]{12}{*}{ Asparagaceae } & Agave angustifolia & EOP & - & - & - & 5 & & 5 \\
\hline & Agave ellemeetiana & EOP & - & - & - & - & 33 & 33 \\
\hline & Cordyline australis & EOP & - & 1 & - & - & - & 1 \\
\hline & Cordyline fruticosa cv. & EOP & - & - & - & - & 34 & 34 \\
\hline & Dracaena cv. & EOP & - & - & - & 5 & 14 & 19 \\
\hline & Dracaena deremensis & EOP & - & - & - & - & 5 & 5 \\
\hline & Dracaena fragrans & EOP & - & - & - & - & 5 & 5 \\
\hline & Dracaena marginata & EOP & - & - & - & - & 49 & 49 \\
\hline & Sansevieria trifasciata & EOP & - & - & - & - & 10 & 10 \\
\hline & Sansevieria zeylanica & EOP & 130 & - & - & - & & 130 \\
\hline & Yucca aloifolia & EOP & - & - & - & - & 1 & 1 \\
\hline & Yucca aloifolia var. & EOP & - & - & - & - & 13 & 13 \\
\hline Asteraceae/ & Cosmos sulphurous & EOP & - & - & - & - & 219 & 219 \\
\hline \multirow[t]{3}{*}{ Compositae } & Helianthus annuus & EOP & - & - & - & - & 590 & 590 \\
\hline & Wedelia sp. & EOP & 300 & - & - & - & 546 & 846 \\
\hline & Zinnia elegans & EOP & & - & - & - & 713 & 713 \\
\hline Boraginaceae & Ehretia microphylla & EOP & 3 & 10 & 121 & - & 2174 & 2308 \\
\hline Bromeliaceae & Achemia fulgens & $\mathrm{EOP}$ & - & - & - & - & 7 & 7 \\
\hline Cactaceae & Lemaireocereus stellatus & EOP & - & - & - & 8 & 8 & 16 \\
\hline Cannaceae & Canna sp. & EOP & - & - & - & - & 625 & 625 \\
\hline
\end{tabular}


Table 5. continued

\begin{tabular}{|c|c|c|c|c|c|c|c|c|}
\hline Family & Species & Status & $\begin{array}{c}\text { Heritage } \\
\text { Park }\end{array}$ & $\begin{array}{c}\text { Hamabar } \\
\text { Park }\end{array}$ & $\begin{array}{c}\text { Fuente } \\
\text { Osmeña } \\
\text { Circle }\end{array}$ & $\begin{array}{c}\text { Senior } \\
\text { Citizen's } \\
\text { Park }\end{array}$ & $\begin{array}{c}\text { Plaza } \\
\text { Indepen- } \\
\text { dencia }\end{array}$ & Total \\
\hline Capparaceae & Cleome spinosa & EOP & - & - & - & - & 187 & 187 \\
\hline Caricaceae & Carica papaya & EOP & - & - & - & 3 & - & 3 \\
\hline Casuarinaceae & Casuarina equisetifolia & EOP & - & - & - & - & 2 & 2 \\
\hline Combretaceae & Terminalia catappa & EOP & - & - & 4 & - & 1 & 5 \\
\hline Commelinaceae & Setcreasea pallida & EOP & - & 52 & 158 & - & 157 & 367 \\
\hline Crassulaceae & Bryophyllum pinnatum & EOP & - & - & - & - & 76 & 76 \\
\hline \multirow[t]{2}{*}{ Ebenaceae } & Diospyros philippinensis & NOP & - & - & - & - & 3 & 3 \\
\hline & Diospyros sp. & EOP & - & - & - & - & 2 & 2 \\
\hline \multirow[t]{4}{*}{ Euphorbiaceae } & Euphorbia milli cv. & EOP & - & - & - & 30 & 133 & 163 \\
\hline & Euphorbia tirucalli & EOP & 14 & - & - & - & 2 & 16 \\
\hline & Hevea brasiliensis & EOP & - & - & - & - & 3 & 3 \\
\hline & Pedilanthus tithymaloides $\mathrm{cv}$. & EOP & - & 46 & - & - & 597 & 1235 \\
\hline \multirow[t]{7}{*}{ Fabaceae } & Acacia sp. & EOP & - & - & 2 & - & 12 & 14 \\
\hline & Calliandra surinamensis & EOP & - & - & - & - & 1 & 1 \\
\hline & Cassia fistula & EOP & - & - & 3 & - & - & 3 \\
\hline & Cassia javanica & EOP & - & - & - & - & 2 & 2 \\
\hline & Delonix regia & EOP & - & 1 & 2 & - & 15 & 18 \\
\hline & Pithecellobium dulce & EOP & - & - & - & - & 6 & 6 \\
\hline & Pterocarpus sp. & EOP & - & - & 32 & 6 & 12 & 50 \\
\hline Heliconiaceae & Heliconia sp. & EOP & 1724 & - & - & - & 379 & 2103 \\
\hline \multirow[t]{2}{*}{ Lamiaceae } & Coleus blumei cv. & EOP & - & - & - & - & 104 & 104 \\
\hline & Gmelina arborea & EOP & - & - & 10 & - & - & 10 \\
\hline Lauraceae & Cinnamomum cebuense & NOP & - & - & - & - & 1 & 1 \\
\hline Lythraceae & Lagerstroemia speciosa & EOP & - & - & - & - & 7 & 7 \\
\hline Malvaceae & Hibiscus sp. & EOP & - & 2 & - & - & 31 & 33 \\
\hline \multirow[t]{2}{*}{ Meliaceae } & Swietenia macrophylla & EOP & - & - & 13 & - & 8 & 21 \\
\hline & Swietenia mahogani & EOP & - & - & - & - & 2 & 2 \\
\hline \multirow[t]{5}{*}{ Moraceae } & Artocarpus heterophyllus & EOP & - & - & - & - & 1 & 1 \\
\hline & Ficus benjamina & EOP & - & - & - & - & 9 & 9 \\
\hline & Ficus religiosa & EOP & 5 & - & 2 & - & 7 & 14 \\
\hline & Ficus sp. & EOP & - & - & - & - & 2 & 2 \\
\hline & Ficus variegata & EOP & - & - & - & 337 & 615 & 952 \\
\hline Moringaceae & Moringa oleifera & EOP & - & - & - & - & 2 & 2 \\
\hline \multirow[t]{2}{*}{ Myrtaceae } & Eucalyptus sp. & EOP & - & - & - & - & 2 & 2 \\
\hline & Syzygium cumini & EOP & - & - & 5 & - & 1 & 6 \\
\hline \multirow[t]{2}{*}{ Nyctaginaceae } & Bougainvillea sp. & EOP & - & 49 & 364 & 1 & 264 & 678 \\
\hline & Mirabilis jalapa & EOP & - & - & - & - & 1 & 1 \\
\hline Oleaceae & Jasminum sambac & EOP & 15 & - & - & - & - & 15 \\
\hline Orchidaceae & Dendrobium sp. & EOP & - & - & - & - & 9 & 9 \\
\hline Podocarpaceae & Podocarpu smacrophyllus & EOP & - & - & - & - & 13 & 13 \\
\hline Plumbaginaceae & Plumbago auriculate & EOP & - & - & - & - & 2 & 2 \\
\hline Poaceae & Bambusa vulgaris & EOP & - & - & - & - & 43 & 43 \\
\hline Rubiaceae & Ixora sp. & EOP & 182 & 50 & 7 & 3295 & 4363 & 7897 \\
\hline \multirow[t]{2}{*}{ Rutaceae } & Citrofortunella sp. & EOP & - & - & - & - & 1 & 1 \\
\hline & Murraya paniculate & EOP & - & 6 & - & - & - & 6 \\
\hline Sapotaceae & Chrysophyllum caimito & EOP & - & - & 1 & - & 1 & 2 \\
\hline Scrophulariaceae & Leucophyllum frutescens & EOP & - & 7 & & 56 & 1282 & 1345 \\
\hline \multirow[t]{2}{*}{ Solanaceae } & Capsicum frutescens & EOP & - & - & - & - & 2 & 2 \\
\hline & Cestrum nocturnum & EOP & - & - & - & - & 1 & 1 \\
\hline Verbenaceae & Duranta erecta & EOP & - & - & 5 & 203 & 3468 & 3676 \\
\hline
\end{tabular}


ellemeetiana, Agave angustifolia, Cordyline fruticosa cv., Cordyline australis, Dracaena cv., Dracaena deremensis, Dracaena fragrans, Dracaena marginata, Sansevieria trifasciata, Sanseviera zeylanica, Yucca aloifolia, Yucca aloifolia var.), Fabaceae with nine genera and nine species (Calliandra surinamensis,Delonix regia, Pithecellobium dulce, Samanea saman, Pterocarpus sp., Cassia javanica, Cassia fistula, Gmelina arborea, Swietenia macrophylla) and Arecaceae/Palmae with eight genera and eight species (Cocos nucifera, Dypsis sp., Licuala grandis, Ptychosperma macarthurii, Veitchia merrillii, Pinanga kuhlii, Rhapis excelsa cv., Roystonea regia).

The majority of the species belonged to families that were non-native, with two species documented as invasive (Swietenia macrophylla and Syzygium cumini) based on the Global Invasive Species Database. The biggest of the sampled parks with an area of $24700 \mathrm{~m}^{2}$, Plaza Independencia, which was also categorized as old park, had a total of 20442 individual plants. The EOPs represented a very large portion of the plants (99.39\%, 20317 individuals) and only $0.61 \%$ of plants were NOPs (125 individuals). There was a total of 85 plant taxa and 74 genera, belonging to 46 families. The most dominant family was Asparagaceae with six genera and nine species, followed by Apocynaceae (six genera and six species) and Fabaceae (six genera and six species). In Plaza Independencia both herbaceous plants (36.47\%) and trees $(36.47 \%)$ dominated in terms of richness of life forms compared to shrubs $(27.06 \%)$. On the other hand, shrubs $(63.46 \%)$ dominated over herbaceous plants $(34.32 \%)$ and trees $(2.22 \%)$ in terms of abundance. The abundance of shrubs can be explained by their functional use in the parks. Shrubs such as Ehretia microphylla and Duranta erecta were used as fences or utilized to define different sections in the park. The categorical and functional classification of Plaza Independencia, which is an old and historic protection park, might have a significant impact on the plant community composition. Trees, although high in species richness, had low abundance because individuals covers a greater area. Moreover, Plaza Independencia contains historical ruins, monuments, and infrastructures, which are intended for human recreational activities. The selection of plants favours shrubs and herbaceous species to meet the need in the area in terms of maximizing space for other purposes.

The Senior Citizen's Park $\left(3510 \mathrm{~m}^{2}\right)$, despite being categorized as a minor and new park, followed Plaza Independencia in plant abundance with 14.09\% (4036 individuals). The park had 17 plant species from 16 genera belonging to 14 families. Individuals of shrub Ixora sp. dominated the landscape with $81.64 \%$ of the total abundance. All documented plant species were identified as EOPs. Ixora sp. were widely used in Senior Citizen's Park as hedges. In the Senior Citizen's Park, shrub communities dominated the landscape and accounted for $47 \%$ of individuals, followed by the tree community (29\%). Relative abundance of the herbaceous community was $24 \%$ of individuals. In terms of richness, the shrub community had the highest proportion of plant species (97\%), the most abundant being Ixora sp., Ficus variegata and Duranta erecta. Ixora sp. was the main ornamental plant inside the park with a total number of 3295 individuals while the Ficus variegata was planted as a fence that surrounded the park. The tree community had the lowest proportion of species, accounted for $1 \%$ of species and was dominated by Ptychosperma macarthurii.

Fuente Osmeña Circle with a land area of $12280 \mathrm{~m}^{2}$, with a total of 1322 individuals from 17 species. These identified plant species belonged to different genera from 14 families. One species was documented as a NOP (Terminalia catappa) and two were listed as invasive (Swietenia macrophylla and Syzygium cumini).

The Heritage Park comprised $8.51 \%$ of the total abundance, with 2438 individuals from 10 families. All identified ornamental plants species found were EOPs. The shrub community in Heritage Park had the largest part (64\%) of species, and was represented by seven species (Ehretia microphylla, Ixora spp., Jasminum sambac, Rhapis excelsa cv., Allamanda neriifolia, Adenium obesum, and Euphorbia tirucalli). The herbaceous plant community with $27 \%$ of species was represented by four (Sanseviera zeylanica, Heliconia sp., and Wedelia trilobata). The tree community had only one species (Ficus religiosa) and accounted for $9 \%$ of species. As the shrub community in Heritage Park had the highest number of species, compared to the herbaceous and tree communities, this may suggest that the minor, new, and historical protection park highlights the architectural structure of the area rather than plant richness. Furthermore, management favours the selection of a shrub community because structurally contains small to medium size plants. Trees were possibly least selected as ornamental plants in the park because of the location and size of the area.

The park with lowest plant species abundance, Plaza Hamabar, comprised only $1.43 \%$ (409 individuals) of the total abundance, with 18 species of EOPs belonging to 15 different families.

Five species of the NOPs were documented in Plaza Independencia, while other parks had no NOPs present. The native species included Cinnamomum cebuense, Diospyros philippinensis, Coleus blumei, Terminalia catappa, and Veitchia merrillii. Consequently, native plants represented only $0.61 \%$ (125 individuals) of the total abundance and $5.88 \%$ of the species richness. Cinnamomum cebuense is endemic to Cebu Island, Philippines and is currently listed by the International Union for Conservation of Nature as critically endangered. Another native species that was occurred in the park was Diospyros philippinensis. Listed as an endemic species, Diospyros philippinensis has been threatened by human intervention in its natural habitat and has now reached an endangered status.

The total abundance of individuals of ornamental 
Table 2. Summary of species abundance, richness, and diversity of exotic and native ornamental plants in surveyed urban parks in Metro Cebu, Philippines. $N$, abundance; $R$, taxa (species) richness; $H$, Shannon diversity index; $D$, Simpson diversity index; $H$ '-Shannon-Weiner diversity index

$\begin{array}{lccccc}\text { Sampling site } & \boldsymbol{N} & \boldsymbol{R} & \boldsymbol{H} & \boldsymbol{D}^{\prime} & \boldsymbol{H}^{\prime} \\ \text { Heritage Park } & 2438 & 11 & 0.441620031 & 0.476250234 & 1.058958584 \\ \text { Plaza Hamabar } & 409 & 18 & 0.742829957 & 0.84951102 & 2.14705473 \\ \text { Fuente Circle } & 1322 & 17 & 0.530051767 & 0.700706955 & 1.501749738 \\ \text { Senior Citizen's Park } & 4036 & 17 & 0.2734329 & 0.323635115 & 0.77469374 \\ \text { Plaza Independencia } & 20442 & 85 & 0.624724838 & 0.896183824 & 2.775434588 \\ \text { All parks } & 28647 & 100 & 0.595377235 & 0.88254802 & 2.74181349\end{array}$

plants in the parks was 28 647. Among them, 20442 were found in Plaza Independencia, 4036 were documented in Senior Citizen's Park, 1322 individuals were recorded in Fuente Osmeña Circle, 2438 were reported in Heritage Park and the remaining 409 individual plants were documented in Plaza Hamabar (Table 2). Results on biological indices showed that for Shannon and Simpson diversity indices, Plaza Independencia had highest diversity. Meanwhile, Senior Citizen has the lowest value of both Shannon and Simpson indices indicating that this sampling site was the least diverse. Plaza Hamabar had highest evenness, while the lowest was for the Senior Citizen's Park (Table 2).

\section{Discussion}

In general, most urban parks in Metro Cebu had high richness and abundance of EOPs. The frequency of EOPs was even higher when species were included that were NOPs to the other urban green spaces outside Cebu. The occurrence of EOPs in urban ecosystems is due to (i) deliberate use, especially for landscaping purposes (Grunewald et al. 2017), or introduction in agriculture, especially in horticulture, and (ii) accidental dispersal (e.g., by car traffic; Hulme 2011). In several countries, the practice of using EOPs for landscaping is directly related to colonial heritage and high urbanization (Knize et al. 2019). Numerous plant species from around the world are used for ornamental purposes, ignoring native flora (Lefcheck et al. 2015). The consequence of urbanization to biodiversity protection may be localized, but has been cumulatively progressing, especially in urban areas like Cebu, with high endemism (Secretariat of the Convention on Biological Diversity 2012; Alvarico et al. 2019). This trend has been observed in other published studies of urban parks. For instance, in the study of Nielsen et al. (2014), it was shown that there was a negative trend for the native-exotic plant ratio, where EOPs has higher species richness than NOPs.

In older parks, it is expected that there will be fewer trees in terms of abundance, but greater species diversity compared to the newly established parks (Gopal, Nagendra 2010). Higher abundance of trees may also indicate a negative impact to herbaceous vegetation, as usually there is a reduced species richness of herbaceous vegetation associated with higher tree numbers (Loydi et al. 2013). Higher tree cover might also promote accumulation of certain soil minerals, such as nitrogen and aluminum, which would later lead to soil acidification (Loydi et al. 2013). Furthermore, success of tree seedling establishment is affected by competition with herbaceous plant forms specific to savannas and grasslands (Davis et al. 2001).

Moreover, the use of EOPs has been also promoted by government agencies (Morris et al. 2014). These species were introduced through research programmes, which were aimed to investigate the medicinal potential, use as new crops and education (Muller et al. 2010). Some of these introduced species escaped and become naturalized, and are currently widely distributed in most parts of the world. The introduction of EOPs can alter the dynamics of NOPs in nearby communities (Pysek et al. 2012; Russo, Cirella 2018). Although usually EOPs have higher richness and floristic diversity than native species in tropical urban ecosystems (Schuldt et al. 2019), most animals, particularly insects, prefer to visit NOPs. It is true that EOPs may pose a health risk to NOPs in the long run and compete with NOPs for insects, reducing the frequency of visits of native species (Van Kluenen et al. 2018). Invasive and generalist species may be more frequent in urban ecosystems and promote plant inbreeding, compromising the cross-pollination process and negatively affecting reproductive success and biodiversity of NOPs.

Among the 100 plant taxa recorded in the study, four species (Casuarina equisetifolia, Terminalia catappa, Swietenia macrophylla, Syzygium cumini) were documented as invasive species in the Philippines. These taxa have been also documented to be invasive in different parts of the world (GISD 2019). The IUCN Invasive Species Specialist Group listed Casuarina equisetifolia as an invasive species in Florida, where it disrupts communities of some reptiles. Terminalia catappa, an indigenous and also invasive tree in the Philippines, has invaded Unites States and several Caribbean and Cayman Islands. Syzygium cumini was also listed in Hawaii, and has been very invasive in the Cook Islands and French Polynesia (GISD 2019). Sri Lanka also reported the invasiveness of Swietenia macrophylla in disturbed forest (Norghauer et al. 2011). The tree was deliberately introduced in both Philippines and Sri Lanka 
for forestry. In general, the invasive plant species found in the present study were widely cultivated in the Philippines because of their use as ornamentals, in the timber industry, source for pharmaecuticals etc. These anthropogenic factors are major issues in biodiversity conservation and invasion ecology. Fortunately, the Parks and Playground Commission has been working on eradicating invasive plants in parks as initial step in promoting urban biodiversity. Aside from that, Dr. Macaraya, the head of the Parks and Playground Commission also considered promoting parks that would provide wildlife habitat, especially for avifauna (personal communication). Based on the surveyed data, EOPs were significantly dominant in all sampled parks. This was not surprising, as park planners in Metro Cebu usually imported ornamental plants from various countries outside the Philippines, including Taiwan and Indonesia. This threatened the biodiversity in the area, as EOPs have greater probability to become invasive and bring severe negative impacts to overall ecosystem functioning in the area.

In terms of biodiversity, the Shannon diversity index $(H)$ usually has a value of 1.5 to 3.5 and rarely reaches 4 (Picardal et al. 2011; Valenzuela et al. 2013). Shannon diversity index increases with higher species richness and evenness (Morris et al. 2014; Garces 2019). Of the five parks in the present study, Plaza Independencia had the highest Shannon diversity values, while Senior Citizen's Park had the lowest (Table 2). Similarly, Simpson diversity reflects species richness and relative abundance of each species. A Simpson value a range of 0 and 1 in which 1 represent a high level of diversity while 0 represents no diversity (Barcelona Field Studies Center 2018). Plaza Independencia had the highest Simpson index value while Senior Citizen's Park had the lowest value. Evenness reflects relative abundance of species, being highest when species have similar relative abundance (Garces, Flores 2017). Plaza Hamabar had the highest evenness while Senior Citizen's Park had the lowest value.

The conservation of plant diversity, especially for taxa with endangered or critically endangered status, can be occur in urban parks. Urbanization, while listed as a top threat for biodiversity, can also be a part of the solution (Garces 2019). The five sampled parks accommodate two vulnerable species (Cinnamomum cebuense and Diospyros philippinensis), which are endemic and endangered species. Even though the species pool of the sampled parks consisted of $95 \%$ of EOPs and only $5 \%$ of NOPs, they have been the cradle for these threatened plant species for the past few years. The high diversity observed in sampled parks suggests that they play an important role for maintaining biodiversity in the city. However, EOPs highly contributes to this diversity. Exotic flora has been known to negatively affect native community and seed production of NOPs (Agrawal, Cook-Patton 2014). Moreover, plant richness and abundance also affect the diversity of other species such as arthropods and birds. In an area with high plant diversity, arthropod richness and abundance tend to be directly proportionally higher because the food sources are readily available and there is less competition (Schuldt et al. 2019). Moreover, it has been observed that native plants attract more arthropods compared to exotic species (Agrawal, Cook-Patton 2014). For birds, in addition to plant diversity, plant community structure has also been observed to affect their abundance and richness. Birds (and other animals) are known to have a specific distance from human presence where they do not show alert behavior; this is known as human tolerance. Bird species differ in human tolerance and a complex habitat structure is known to have a positive effect on bird diversity (Wenny et al. 2011). In addition, more-individual hypothesis already predicts this trend on diversity.

\section{Conclusions}

This study documented that urban parks have a high proportion of EOPs. All identified plants in the three minor parks (Senior Citizen's Park, Heritage park and Plaza Hamabar) were all EOPs. In these three parks, only one plant species was found to be native in Fuente Osmeña Circle, but this species is considered to be invasive. Dominance of EOPs over NOPs in the top five most visited parks can be explained by various factors such as park category, functional classification and management options. Further studies should investigate the ecosystem services provided by these EOPs and NOPs, as well as the associated pollinators responsible for the reproductive success of EOPs and NOPs in urban parks, in addition to fruit and seed dispersal and seed viability. This would allow an analysis of the impact of EOPs on the dynamics of urban green spaces, which would be extremely useful for the elaboration of management plans for plant species occurring in several types of urban green spaces (gardens, public roads, green roofs), allowing urban green spaces to act as connecting points to natural areas, thereby maintaining or restoring local biodiversity and ecosystem functioning. The role of urban parks is essential for city's sustainability and thus, evaluating and determining the plants propagated in these parks is one of the imperative ways for a better future planning and effective management strategies not just in parks but also for other urban green spaces in the Philippines.

\section{Acknowledgements}

The authors would like to express their gratitude to Mr. Mark Ian C. Andres and Mrs. Mirasol A. Montaño for their keen and thoughtful comments that contributed to the success of this study. Special thanks to Commission Head of Parks and Playground Commission, Dr. Librado O. Macaraya Jr., for giving his full support in the conduct of the study and to all gardeners and staffs who helped in the initial identification of plants. This 
study was also supported by the Biology Department and Cebu Normal University-Research Institute of Tropical Biology and Pharmacological Biotechnology. Sincere gratitude is given to the anonymous reviewers for their comments and suggestions to improve the manuscript.

\section{References}

Agrawal A., Cook-Patton S. 2014. Exotic plants contribute positively to biodiversity functions but reduce native seed production and arthropod richness. Ecology 95: 1642-1650.

Akhtar N., Bergmeier E. 2015. Species richness, alpha and beta diversity of trees, shrubs and herbaceous plants in the woodlands of swat, Pakistan. Pak. J. Bot. 47: 2107-2113.

Alvarico H.M.L., Geraldizo E.B.P., Tapic J.M.A., Vez M., Tura N.B., Tenio G., Garces J.J. 2019. Floral composition and diversity in Camp 7, Minglanilla, Cebu Island, Philippines with notes on anthropogenic activities. Int. J. Biosci. 15: 229-242.

Barcelona Field Studies Centre. 2018. Simpson's Diversity Index.

Barcelona J., Pelser P. 2015. A manual to using Co's Digital Flora of the Philippines. CDFP Manual.

Baxter J. 2014. Vegetation sampling using the quadrat method. Department of Biological Sciences. California State University, Sacramento.

Burkmar R., Bell C. 2015. Drivers of biodiversity loss: A research synthesis for the tomorrow's biodiversity project. Field Studies Council, Montford Bridge Shrewsbury.

Bellard C., Cassey P., Blackburn T. 2016. Alien species as a driver of recent extinctions. Biol. Lett. 12: 1-4.

Birch E., Wachter S. 2011. World urbanization: The critical issue of the twenty-first century. Global urbanization. University of Pennsylvania Press.

Buczkowski G., Richmond D. 2012. The effect of urbanization on ant abundance and diversity: A temporal examination of factors affecting biodiversity. PLoS One 7: 1-9.

CPDO. 2017. About Cebu City. Cebu City Planning and Development Office.

Coldwell D., Evans K. 2017. Contrasting effects of visiting urban greenspace and the countryside on biodiversity knowledge and conservation support. PLoS One 12: 1-18.

Corcos D., Nascimbene J., Campesan M., Donadello D., Segat V., Marini L. 2020. Establishment dynamics of native and exotic plants after disturbance along roadsides. Appl. Veget. Sci. 23: 277-284.

Crompton J. 2016. Evolution of the "parks as lungs" metaphor: Is it still relevant? World Leis. J. 59: 105-123.

Dehnen-Schmutz K., Conroy J. 2018. Working with gardeners to identify potential invasive ornamental garden plants: testing a citizen science approach. Biol. Invas. 20: 3069-3077.

Downey P., Richardson D. 2016. Alien plant invasions and native plant extinctions: a six-threshold framework. AoB Plants 8: $1-21$.

Eisenhauer N., Vogel A., Jensen B., Scheu S. 2018. Decomposer diversity increases biomass production and shifts aboveground-belowground biomass allocation of common wheat. Sci. Rep. 8: 1-8.

Faeth S., Bang C., Saari S. 2011. Urban biodiversity: Patterns and mechanisms. Ann. New York Acad. Sci. 1223: 69-81.

FAO. 2011. The state of the world's land and water resources for food and agriculture. Food and Agriculture Organization, Abingdon.

Foxcroft L., Pyšek P., Richardson D., Genovesi P., McFadyen S.
2017. Plant invasion science in protected areas: progress and priorities. Biol. Invas. 19: 1353-1378.

Gaertner M.,Wilson J., Cadotte M., MacIvor J.,Zenni R., Richardson D. 2017. Non-native species in urban environments: patterns, processes, impacts and challenges. Biol. Invas. 19: 3461-3469.

Garces J.J. C. 2019. Arthropod functional feeding groups as indicators of small-scale disturbance: a first approach in Mt. Manunggal, Cebu Island, Philippines. Environ. Exp. Biol. 17: 137-149.

Garces J.J. 2019. Native and alien plant species inventory and diversity in disturbed forests and its economic value. Global J. Environ. Sci. Manage. 5: 249-264.

Garces J.J, Genterolizo J.M. 2018. Impacts of anthropogenic activities on alien plant invasion in Mt. Manunggal, Cebu Island, Philippines. J. Biodiv. Environ. Sci. 13: 225-236.

Garces J.J., Flores M. J.L. 2017. Effects of environmental factors and alien plant invasion on native floral diversity in Mt. Manunggal, Cebu Island, Philippines. Curr. World Environ. 13: 390-402.

Garces J.J. C., Jarito Z.O., Barriga L.A.T., Domecillo F.C., Pansit N R. 2016. Practices of entomophagy and entomotherapy in Cebu Island, Philippines. Recol. Multidisc. Res. J. 4: 61-78.

GISD. 2019. Species profile. Global Invasive Species Database.

Grunewald K., Kümper-Schlake L., Li J., Xie G. 2017. The multiple benefits of urban green-ecosystem services assessment. In: Benenson I., Czamanski D., Folmer H., Irwin E. (eds) Towards Green Cities: Urban Biodiversity And Ecosystem Services in China and Germany. Springer International Publishing AG, Switzerland, pp. 43-104.

Guiaşu R., Tindale C. 2018. Logical fallacies and invasion biology. Biol. Phil. 33: 1-24.

Hanski I. 2011. Habitat loss, the dynamics of biodiversity, and a perspective on conservation. Ambio 40: 248-255.

Hulme P.E. 2011. Addressing the threat to biodiversity from botanic gardens. Trends Ecol. Evol. 26: 168-174.

Hummel D., Adamo S., de Sherbinin A., Murphy L., Aggarwal R., Zulu L., Knight K. 2013. Inter- and transdisciplinary approaches to population-environment research for sustainability aims: a review and appraisal. Popul. Environ. 34: 481-509.

IUCN. 2015. Global business and biodiversity program. International Union for Conservation of Nature.

Jeschke J., Bacher S., Blackburn T., Dick J., Essl F., Evans T., Gaertner M., Hulme P., Kühn I., Mrugała A., Pergl J., Pyšek P., Rabitsch W., Ricciardi A., Richardson D., Sendek A., Vilà M., Winter M., Kumschick S. 2014. Defining the impact of nonnative species. Conserv. Biol. 28: 1188-1194.

Kruize H., van der Vliet N., Staatsen B., Bell R., Chiabai A., Muiños G., Higgins S., Quiroga, S., Martinez-Juarez P., Aberg Yngwe M., Tsichlas F., Karnaki P., Lima M., García de Jalón S., Khan M., Morris G., Stegeman I. 2019. Urban green space: creating a triple win for environmental sustainability, health, and health equity through behavior change. Int. J. Environ. Res. Public Health 16: 4403.

Lefcheck J., Byrnes J., Isbell F., Gamfeldt L., Griffin J. 2015. Biodiversity enhances ecosystem multifunctionality across trophic levels and habitats. Nat. Commun. 6: 6936.

Leger E., Espeland E. 2010. Coevolution between native and invasive plant competitors: implications for invasive species management. Evol. Appl. 3: 169-178.

Li Z., Chen D., Cai S., Che S. 2018. The ecological services of plant communities in parks for climate control and recreation-A 
case study in Shanghai, China. PLoS One 13: e0196445.

Lundholm J., Richardson P. 2010. Mini review: Habitat analogues for reconciliation ecology in urban and industrial environments. J. Appl. Ecol. 47: 966-975.

Morris E., Caruso T., Buscot F., Fischer M., Hancock C., Maier T., Meiners T., Müller C., Obermaier E., Prati D., Socher S., Sonnemann I., Wäschke N., Wubet T., Wurst S., Rillig M. 2014. Choosing and using diversity indices: insights for ecological applications from the German Biodiversity Exploratories. Ecol. Evol. 4: 3514-3524.

Müller N., Werner P. 2010. Urban biodiversity and the case for implementing the convention on biological diversity in towns and cities. In: Müller N., Kelcey J.G., Werner P. (eds) Urban Biodiversity and Design. Blackwell Publishing, Oxford, pp. 3-33.

Nielsen A., Maruthaveeran S., van den Bosch C.K., van den Bosch M. 2014. Species richness in urban parks and its drivers: A review of empirical evidence. Urban Ecosyst. 17: 305-327.

Norghauer J., Martin A., Mycroft E., James A., Thomas S. 2011. Island invasion by a threatened tree species: evidence for natural enemy release of mahogany (Swietenia macrophylla) on Dominica, Lesser Antilles. PLoS One 6: e18790.

OECD. 2017. Green Growth Studies: Green Growth in Cebu, Philippines. Organization for Economic Co-operation and Development. OECD Publishing, Paris.

Pascual U., Muradian R., Brander L., Gomez-Baggethun E., Martín-López B., Verma M., Armsworth P., Christie M., Cornelissen J., Eppink F., Farley J., Loomis Pearson L., Perrings C., Polasky S. 2010. The Economics of Valuing Ecosystem Services and Biodiversity. In: Kumar P. (ed) The Economics of Ecosystem and Biodiversity. Routledge, Oxon, pp. 183-256.

Philippine Atmospheric Geophysical Astronomical Services Administration (PAGSA) 2015. Dry spell/drought assessment. Philippine Atmospheric, Geophysical and Astronomical Services Administration, Department of Science and Technology.

Picardal J.P., Avila S.T.R. Tano M.F. Marababol M.S. 2011. The species composition and associated fauna of the mangrove forest in Tabuk and Cabgan Islets, Palompon, Leyte, Philippines. CNU J. Higher Educ. 5: 1-18.

Powell K., Knight T., Chase J. 2011. A synthesis of plant invasion effects on biodiversity across spatial scales. Am. J. Bot. 98: 539-548.

Pyšek P., Jarošík V., Hulme P. E., Pergl J., Hejda M., Schaffner U., Vilà M.2012. A global assessment of invasive plant impacts on resident species, communities and ecosystems: the interaction of impact measures, invading species' traits and environment. Global Change Biol. 18: 1725-1737.

Replan E., Malaki A. 2017. Floral diversity and habitat assessment of Canbantug Forest, Argao, Central Visayas, Cebu, Philippines. Int. J. Sci. Eng. Res. 8: 775-780.

Riffat S., Powell R., Aydin D. 2016. Future cities and environmental sustainability. Fut. Cities Environ. 2: 1.

Russo A., Cirella G. 2018. Modern compact cities: how much greenery do we need? Int. J. Environ. Res. Publ. Health 15: 1-15.
Schuldt A., Ebeling A., Kunz M., Staab M., Guimarães-Steinicke C., Bachmann D., Buchmann N., Durka W., Fichtner A., Fornoff F., Härdtle W., Hertzog L., Klein A., Roscher C., Schaller J., von Oheimb G., Weigelt A., Weisser W., Wirth C., Zhang J., Bruelheide H. Eisenhauer N. 2019. Multiple plant diversity components drive consumer communities across ecosystems. Nature Commun. 10: 1460.

Scovronick N., Budolfson M., Dennig F., Fleurbaey M., Siebert A., Socolow R., Spears D. Wagner F. 2017. Impact of population growth and population ethics on climate change mitigation policy. Proc. Nat. Acad. Sci. USA 114: 12338-12343.

Secretariat of the Convention on Biological Diversity. 2012. Cities and Biodiversity Outlook. Montreal.

Tam K., Bonebrake T. 2016. Butterfly diversity, habitat and vegetation usage in Hong Kong urban parks. Urban Ecosyst. 19: 721-733.

Tan D., Thu P., Dell B. 2012. Invasive plant species in the national parks of Vietnam. Forests 3: 997-1016.

Tobin P. 2018. Managing invasive species. F1000 Faculty Rev. 7: 1686.

Ummeh S., Toshio K. 2017. Classification of urban parks and their regional characteristics in Dhaka City, Bangladesh. J. Environ. Sci. Eng. B 6: 41-54.

UN. 2013. World economic and social survey 2013: Sustainable development and challenges. United Nations, Department of Economic and Social Affairs.

UNDP. 2014. Biodiversity for sustainable development: delivering results for Asia and the pacific. United Nations Development Program.

UNEP. 2012. Decoupling natural resource use and environmental impacts from economic growth. United Nations Environment Program Division of Technology Industry and Economics, Paris.

Valenzuela H.Y., Bacalso A.D., Gano C.B., Pilones K.D., Picardal J.P. 2013. The species composition and associated flora and fauna of the mangrove forest in Badian, Cebu Island, Philippines. IAMURE Int. J. Mar. Ecol. 1: 1-23.

van Ham C., Genovesi P., Scalera R.2013. Invasive alien species: the urban dimension, Case studies on strengthening local action in Europe. Brussels, Belgium: IUCN European Union Representative Office.

Van Kluenen M., Essl F., Pergl J., Burdu G., Carboni M., Early R., Groom Q., Hulme P., Kueffer C., Kuhn I., Maguas C., Maurel N., Novoa A., Parepa M., Pysek P., Seebens H., Tanner R., Touza J., Verbrugge L., Weber. E., Dauson W., Kreft H., Weigett P., Winter M., Klonner G., Talluro M., Dehnen-Schmutz K. 2018. The changing role of ornamental horticulture of alien plant invasions. Biol Rev. 93: 1421-1437.

Wenny D., Devault T., Johnson M., Kelly D., Sekercioglu C., Tomback D., Whelan C. 2011. The need to quantify ecosystem services provided by birds. The Auk 128: 1-14.

Yang M., Lu Z., Liu X., De Wulf R., Hens L., Ou X. 2018. Association of non-native plant species with recreational roads in a national park in the Eastern Himalayas, China. Mount. Res. Dev. 38: 53-62. 